\title{
Effects of histone deacetylase inhibition on the survival, proliferation and migration of Schwann cells, as well as on the expression of neurotrophic factors and genes associated with myelination
}

\author{
YAZHOU WANG ${ }^{1 *}$, XINGJUN WU ${ }^{2 *}$, YUEPING ZHONG ${ }^{3}$, JIANHONG SHEN $^{3}$, \\ XINHUA WU ${ }^{4}$, SHAOQING JU ${ }^{1,4}$ and XIAOFEI WANG ${ }^{1,5}$ \\ ${ }^{1}$ Laboratory Medicine Center, Affiliated Hospital of Nantong University, Nantong, Jiangsu 226001; \\ ${ }^{2}$ Department of Neurology, Xuhui Central Hospital, Xuhui, Shanghai 200031; ${ }^{3}$ Department of Neurosurgery, \\ ${ }^{4}$ Surgical Comprehensive Laboratory, Affiliated Hospital of Nantong University, Nantong, Jiangsu 226001, P.R. China; \\ ${ }^{5}$ Stark Neurosciences Research Institute, Indiana University School of Medicine, Indianapolis, IN 46202, USA
}

Received December 2, 2013; Accepted May 6, 2014

DOI: 10.3892/ijmm.2014.1792

\begin{abstract}
Trichostatin A (TSA), a histone deacetylase (HDAC) inhibitor, has been shown to have neuroprotective, neurotrophic and anti-inflammatory properties in both animal and cellular models of neurodegenerative disorders. In a previous study of ours, we demonstrated that TSA inhibited the proliferation and increased the differentiation of neuronal precursor cells (NPCs). However, the effects of TSA on Schwann cells (SCs) have not yet been fully elucidated. Thus, in the present study, using SCs derived from adult rat sciatic nerves, we investigated the effects of TSA on the survival, proliferation, migration and myelination of SCs. We found that TSA significantly induced SC death when used at high concentrations. We also observed that TSA promoted the proliferation of SCs in a time-dependent manner. In addition, TSA inhibited the migration of SCs. Moreover, RT-PCR revealed that TSA increased the mRNA expression of several neurotrophic factors and inhibited the expression of genes associated with myelination, including myelin basic protein (MBP) and myelin protein zero (MPZ). Taken together, our results suggest that TSA plays an important role in regulating the growth and biological function of SCs. These data may contribute to our understanding of TSA-based treatment of neurodegenerative diseases.
\end{abstract}

Correspondence to: Dr Xiaofei Wang, Stark Neurosciences Research Institute, Indiana University School of Medicine, 950 W. Walnut Street, R-3 Building C432, Indianapolis, IN 46202, USA

E-mail: ntwxf001@163.com

*Contributed equally

Key words: histone deacetylase, trichostatin A, Schwann cell, survival, proliferation, migration

\section{Introduction}

It has been widely accepted that the key to repairing neurodegenerative disorders, such as spinal cord injury (SCI), is to inhibit inflammation and promote neuronal survival, axonal regeneration and remyelination. In recent years, cell transplantation and neuroprotective pharmaceuticals are the two main strategies for the treatment of SCI. Various studies have demonstrated that the transplantation of neuronal stem cells/neuronal precursor cells (NSCs/NPCs) (1,2), Schwann cells (SCs) $(3,4)$, olfactory ensheathing cells (OECs) $(4,5)$ and bone marrow stromal cells (BMSCs) (6) significantly improves the outcome of SCI.

It has been demonstrated that SC transplantation offers a certain degree of remyelination and functional restoration, reduces tissue damage (5) and neuronal cell loss, promotes axon regeneration (7) and remyelination (8), and thus enhances the functional outcome (5) of SCI. Although SC transplantation is beneficial in models of experimental SCI, the low survival rate of these cells post-transplantation limits their effectiveness. It has been reported that only $20 \%$ of the grafted SCs survive $(3,7,9)$. The death of grafted SCs may be attributed to low oxygen levels, oxidative metabolites, inflammatory cytokines and a cell-mediated immune response $(3,9)$, as well as to the withdrawal of trophic/mitogenic factors when the cells are removed from their pre-transplantation culture conditions (9).

Previous studies have confirmed that histone deacetylase (HDAC) inhibitors, such as trichostatin A (TSA) and valproic acid (VPA), have neuroprotective, neurotrophic and anti-inflammatory properties. These inhibitors have been shwon to not only improve neurological performance in animal models of neurodegenerative disorders, such as traumatic brain injury (10), stroke (11), amyotrophic lateral sclerosis (12), spinal muscular atrophy (13), and Huntington's disease (14), but also to play a neuroprotective role in cellular models, including models of oxidative stress-induced cortical neuronal death (15), glutamate-induced neuronal excitotoxicity (16) and lipopoly- 
saccharide (LPS)-induced microglial and neuronal death (17). In a recent study or ours, we found that TSA increased neuronal differentiation and decreased the astrocyte differentiation of NPCs. Morevover, we demonstrated that TSA had no effect on the survival of NPCs (18). However, to the best of our knowledge, there is no report available to date on the effects of TSA on SCs. Thus, in the present study, we investigated the effects of TSA on the survival, proliferation and migration of SCs, as well as on the expression of neurotrophic factors genes and genes associated with myelination in rat SCs in primary culture.

\section{Materials and methods}

Isolation and culture of SCs. The methods for SC isolation, purification and amplification were developed by Morrissey et al (19) and described in previous studies $(22,23)$. Briefly, sciatic nerves were obtained from adult SpragueDawley rats (200 g body weight; Central Animal Laboratory, Nantong University, Nantong, China) anaesthetized with ketamine $(87.7 \mathrm{mg} / \mathrm{kg}$; Ben Venue Laboratories, Bedford, $\mathrm{OH}$, USA) and xylazine (12.3 mg/kg; Butler, Columbus, OH, USA) under aseptic conditions. After the epineurium (outermost layer of connective tissue) was removed, the nerves were cut into $1 \mathrm{~mm}$-long explants. The explants were placed in $35-\mathrm{mm}$ tissue culture dishes (Baxter Healthcare Corp., Stone Mountain, GA, USA) with low levels $(0.8 \mathrm{ml})$ of DMEM supplemented with $10 \%$ fetal bovine serum (FBS; Invitrogen, Carlsbad, CA, USA), termed as D10. When the outgrowth of migratory cells (predominantly fibroblasts) reached a near-confluent monolayer around the explants (7 days), the explants were transferred to new culture dishes containing fresh medium. After 5-6 such passages (5-6 weeks), the cells that emerged from the explants were primarily SCs. The explants were then transferred to a 35-mm dish containing 1.25 U/ml dispase (Boehringer Roche Mannheim Biochemicals, Indianapolis, IN, USA), 0.05\% collagenase (Worthington Biochemicals Corp., Lakewood, NJ, USA) and $15 \%$ FBS in DMEM for incubation overnight at $37^{\circ} \mathrm{C}$ in $5 \% \mathrm{CO}_{2}$. On the following day, the explants were dissociated and the cells were plated onto poly-L-lysine (PLL)-coated $100 \mathrm{~mm}$ dishes in DMEM/10\% FBS (D10). Subsequently, the cultures were re-fed with D10 supplemented with $20 \mu \mathrm{g} /$ $\mathrm{ml}$ pituitary extract [Biomedical Technologies, Inc. (BTI), Stoughton, MA, USA) and $2 \mu \mathrm{M}$ forskolin (Sigma, St. Louis, MO, USA), termed as D10/PF, for proliferation. When the SCs reached confluence, they were rinsed in $\mathrm{Ca}^{2+}$ - and $\mathrm{Mg}^{2+}$-free Hank's balanced salt solution (CMF-HBSS) and briefly treated with $0.05 \%$ trypsin and $0.02 \%$ EDTA (all from Gibco, Langley, OK, USA) in CMF-HBSS. The cells were washed twice in D10 and passed into new dishes at a density of $2 \times 10^{6}$ cells $/ 100 \mathrm{~mm}$ dish. The purity of the SCs (percentage of p $75^{+}$cells in all cells) was quantified according to a previously described method (21). All the Cs used in this study were passage 2 (P2) cells with a purity of $>98 \%$.

Cytotoxicity assay. The effect of TSA on SC survival was evaluated by measuring lactate dehydrogenase (LDH) activity released in the medium $24 \mathrm{~h}$ following exposure to TSA $(0.1,1,10$ and $100 \mathrm{ng} / \mathrm{ml})$ using the CytoTox $96^{\oplus}$ nonradioactive assay (Promega Corp., Southampton, UK) and quantified by measuring wavelength absorbance at $490 \mathrm{~nm}$.
SCs were collected from culture and single cells were seeded in PLL-coated 96-well plates $\left(4.0 \times 10^{4}\right.$ cells/100 $\mu \mathrm{l} /$ well $)$ and allowed to grow in D10/PF for 4 days. Subsequently, D10/PF $(100 \mu \mathrm{l})$ containing various concentrations of TSA was added to the wells for a further $24 \mathrm{~h}$. Finally, $50 \mu \mathrm{l}$ of supernatants were transferred to an enzymatic assay plate and analyzed according to the manufacturer's instructions. The results are expressed as the means \pm standard deviation $(\mathrm{SD})$ of the percentage of the absorbance in medium from cells grown in various concentrations of TSA compared to the controls (untreated cells) in 6 independent experiments.

Analysis of cell proliferation. The analysis of SC proliferation was carried out by counting the viable cell number using a Cell Counting kit-8 (CCK-8) (Dojindo Laboratories, Kumamoto, Japan). This assay is based on the conversion of watersoluble tetrazolium salt, 2-(2-methoxy-4-nitrophenyl)-3-(4-nitrophenyl)-5-(2,4-disulfophenyl)-2H-tetrazolium, monosodium salt (WST-8) to a water-soluble formazan dye upon reduction in the presence of an electron carrier by dehydrogenases. Briefly, the SCs were dissociated in D10 and single cells were transferred to 96 -well plates $\left(2.0 \times 10^{4} \mathrm{cells} / 100 \mu \mathrm{l} /\right.$ well) allowing them to grow in D10/PF for 3 days. Subsequently, $100 \mu 1$ of D10/PF containing various concentrations of TSA were added to the wells for a further 24, 48 and $72 \mathrm{~h}$. The CCK-8 solution (10 $\mu \mathrm{l})$ was added to each well, and the plates were then incubated at $37^{\circ} \mathrm{C}$ for $5 \mathrm{~h}$. The absorbance at $450 \mathrm{~nm}$ was determined using a multiplate reader (Bio-Rad Laboratories, Hercules, CA, USA). Cell viability was expressed as a percentage of the absorbance values in various concentrations of TSA at 3 time points compared to that in various concentrations of TSA immediately following exposure (control) in 3 independent experiments.

Cell migration assay. To evaluate the effects of TSA on SC migration, a Transwell chamber analysis was performed as described in our previous studies $(18,22)$. SCs $\left(4 \times 10^{5} / \mathrm{ml}\right)$ in $250 \mu \mathrm{l}$ of D10/PF per well were seeded into the upper chamber and were inserted into the tissue-culture wells containing different concentrations of TSA $(0.1$ and $1 \mathrm{ng} / \mathrm{ml})$ at a final volume of $750 \mu \mathrm{l}$ of medium per well. Following incubation for $8 \mathrm{~h}$ at $37^{\circ} \mathrm{C}$, the filters were stained with Coomassie Blue and DAPI; the number of stained, migrated cells at the bottom surface of the filters was counted at 5 fields per filter in 3 independent experiments.

Immunofluorescence. Coverslips with the SCs were rinsed with 0.01 M PBS twice, fixed with 4\% paraformaldehyde for $30 \mathrm{~min}$, and then rinsed with PBS for 10 min, 3 times at room temperature. The coverslips were permeabilized and blocked with $0.3 \%$ Triton X-100/3\% normal goat serum in $0.01 \mathrm{M}$ PBS for $30 \mathrm{~min}$ at $4^{\circ} \mathrm{C}$. Mouse anti-rat S100 primary antibody was applied to the coverslips at $4^{\circ} \mathrm{C}$ overnight. On the following day, the coverslips were incubated with fluorescein-conjugated goat anti-mouse (FITC; 1:400; Chemicon International, Inc., Temecula, CA, USA) antibody for $2 \mathrm{~h}$ at $37^{\circ} \mathrm{C}$. After several PBS rinses, the coverslips were mounted and examined under a Zeiss fluorescence microscope (Carl Zeiss, Jena, Germany). Primary anti-serum omission controls and goat serum controls were used to further confirm the specificity of immunofluorescence labeling. 
Table I. Primers used in RT-PCR and quantitative PCR analysis.

\begin{tabular}{lllr}
\hline Gene & \multicolumn{1}{c}{ Forward primers $\left(5^{\prime}{ }^{\prime} 3^{\prime}\right)$} & \multicolumn{1}{c}{ Backward primers $\left(5^{\prime} \rightarrow 3^{\prime}\right)$} & Size $(\mathrm{bp})$ \\
\hline GAPDH & AAGTTCAACGGCACAGTCAAG & CCAGTAGACTCCACGACATACTA & 137 \\
MBP & GCCAGTAAGGATGGTGAGATTC & TTCTTTGGGTCTGCTGTGTG & 182 \\
MPZ & GCTCCATTGTCATACACAACCTA & ATCAGGTAGAAGAGCAACAGCAG & 208 \\
NGF & CCAAGGACGCAGCTTTCTA & CCTCTGGGACATTGCTATCTG & 132 \\
BDNF & CCGTTTGACAACATTAATCTCTG & GTCTCCTATGAAGCCACCTAATC & 183 \\
GDNF & TTATGGGATGTCGTGGCTGT & TCAGGATAATCTTCGGGCATA & 170 \\
CNTF & GATTCGTTCAGACCTGACTGCT & TACGGTAAGCCTGGAGGTTCT & 167 \\
FGF & TACCTGGCTATGAAGGAAGATG & AGTTCGTTTCAGTGCCACATAC & 147 \\
GGF & GCTGACAATTACTGGCATCTGT & AGGTTGCTCCGTTCTGACC & 138 \\
\hline
\end{tabular}

MBP, myelin basic protein; MPZ, myelin protein zero; BDNF, brain-derived neurotrophic factor; FGF, fibroblast growth factor, GGF, glial growth factor; GDNF, glial cell-derived neurotrophic factor; CNTF, ciliary neurotrophic factor; NGF, nerve growth factor.

Reverse transcription $(R T)-P C R$. The SCs were treated with TSA $(0.1,1,10 \mathrm{ng} / \mathrm{ml})$ or without TSA for $48 \mathrm{~h}$. The cells were washed 3 times with PBS and used for isolating total cellular RNA using TRIzol reagent (Invitrogen) according to the manufacturer's instructions. The quality and quantity of RNA were determined by $1.5 \%$ agarose gel electrophoresis and spectrophotometric analysis, respectively. Reverse transcription for complementary DNA (cDNA) synthesis was performed with $2 \mu \mathrm{g}$ total RNA using RevertAid ${ }^{\mathrm{TM}}$ First Strand cDNA Synthesis kits (Fermentas, Inc., Hanover, MD, USA) with random primers. RT-PCR was performed in total reaction volumes of $20 \mu \mathrm{l}$ using DreamTaq Green PCR Master Mix (2X) (Fermentas) in a MyCycler ${ }^{\mathrm{TM}}$ Thermal Cycler 1709703 instrument (Bio-Rad Laboratories) according to the manufacturer's instructions. The forward and reverse primers of the neurotrophic factors are listed in Table I. The reaction cycle consisted of $95^{\circ} \mathrm{C}$ for $2 \mathrm{~min}$, followed by 30 cycles of $95^{\circ} \mathrm{C}$ for $30 \mathrm{sec}, 55^{\circ} \mathrm{C}$ for $30 \mathrm{sec}, 72^{\circ} \mathrm{C}$ for $30 \mathrm{sec}$ and $72^{\circ} \mathrm{C}$ for $10 \mathrm{~min}$. Samples were analyzed by $2 \%$ agarose gel electrophoresis and the relative expression values of all mRNAs were normalized to the glyceraldehyde-3-phosphate dehydrogenase (GAPDH) mRNA level. The scanned images of the PCR products following agarose gel electrophoresis were quantified using ImageJ software. For each mRNA, the dose dependence of the PCR product was analyzed using a different amount of the input cDNA and 30 cycles of amplification. For all the mRNAs examined in our study, 30 cycles of amplification under our experimental conditions were within the linear range. As the negative controls, RNA samples were subjected to PCR without the reverse transcription reaction.

Quantitative PCR ( $q$ PCR).qPCR was carried out in a 20- $\mu$ l final volume and performed in triplicate using Power SYBR-Green PCR Master Mix reagents (Fermentas) in an ABI Prism 7500 sequence detector (Applied Biosystems, Framingham, MA, USA) according to the manufacturer's instructions. The forward and reverse primers of the genes associated with myelination [such as myelin basic protein (MBP) and myelin protein zero (MPZ)] are listed in Table I. The conditions for qPCR were as follows: $95^{\circ} \mathrm{C}$ for $10 \mathrm{~min}$ followed by 40 cycles at $95^{\circ} \mathrm{C}$ for $10 \mathrm{sec}$ and $60^{\circ} \mathrm{C}$ for $1 \mathrm{~min}$. GAPDH was used as a housekeeping gene for normalization. The effects of TSA on the mRNA levels of the genes associated with myelination were expressed as fold changes normalized to GAPDH using a published comparative method (18) with the formula: $2^{-\Delta \Delta C t}$.

Statistical analysis. One- or two-way ANOVA followed by Fisher's post-hoc tests were used to evaluate the effects of TSA and/or time on the survival, proliferation and migration of $\mathrm{SCs}$, as well as the mRNA expression of neurotrophic factors and genes associated with myelination. The significance level for all comparisons was set at $\mathrm{p}<0.05$. All data are presented as the means $\pm \mathrm{SD}$.

\section{Results}

Identification of SCs. SCs isolated from adult rats exhibited a spindle-like morphology and a swirling cell pattern with parallel cell alignment when cultured in PLL. Over $98 \%$ of these SCs expressed S100, a marker for SCs (Fig. 1).

Effect of HDAC inhibition on SC survival. Cell survival was evaluated by measuring lactic dehydrogenase (LDH) release into the medium from dead or dying cells treated with various concentrations of TSA for $24 \mathrm{~h}$. The results revealed that there was no significant difference between the groups treated with TSA at a concentration of $0.1,1$ and $10 \mathrm{ng} / \mathrm{ml}$ and the control group ( $\mathrm{p}>0.86, \mathrm{n}=6)$. However, when the concentration of TSA reached $100 \mathrm{ng} / \mathrm{ml}, \mathrm{LDH}$ relative absorbance increased by approximately $20 \%$ compared to the control group $(\mathrm{p}<0.05$, $\mathrm{n}=6$; Fig. 2), indicating that a low concentration of TSA $(<10 \mathrm{ng} /$ $\mathrm{ml}$ ) has no direct effect on the survival of SCs, whereas a high concentration of TSA does.

HDAC inhibition promotes the proliferation of SCs. To evaluate the effects of HDAC inhibition on SC proliferation, the SCs were treated with $0.1,1$ and $10 \mathrm{ng} / \mathrm{ml}$ of TSA. Cell proliferation was assessed by counting the total cell number by CCK- 8 assay following the exposure of SCs to TSA for 0, 24, 48 and $72 \mathrm{~h}$. As shown in Fig. 3, TSA increased the proliferation of SCs in 

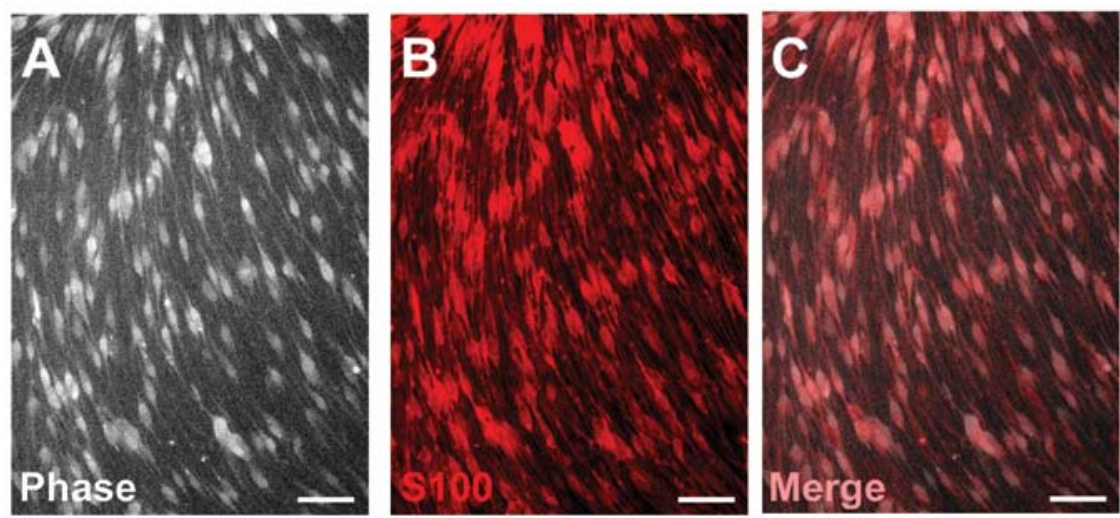

Figure 1. Identification of Schwann cells (SCs). (A) SCs derived from the sciatic nerves of the adult rats were expanded to form a confluent layer in culture. (B) Immunocytochemistry showed that $>98 \%$ of these cells express S100 (red), a specific marker for Schwann cells. (C) Merging of (A) and (B). Scale bars, $20 \mu \mathrm{m}$.

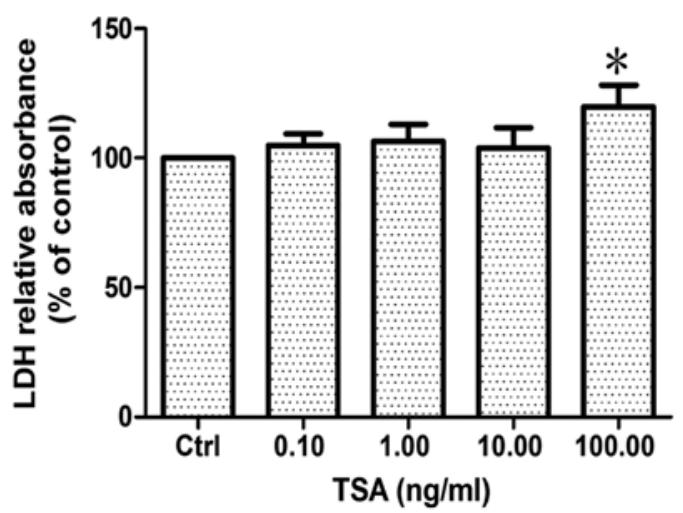

Figure 2. Effect of trichostatin A (TSA) on the survival of Schwann cells (SCs). The release level of lactic dehydrogenase (LDH) showed no significant difference between the groups treated with $0.1-10 \mathrm{ng} / \mathrm{ml}$ TSA and the control group; however, in the group treated with $100 \mathrm{ng} / \mathrm{ml} \mathrm{TSA}$, LDH release significantly increased by approximately $20 \%$ compared with the control group after $24 \mathrm{~h} .{ }^{*} \mathrm{p}<0.05, \mathrm{n}=6$.

a time- and concentration-dependent manner $(\mathrm{p}<0.001)$. The proliferation curve can be clearly observed in the normal culture medium ( $0 \mathrm{ng} / \mathrm{ml}$ TSA) with increased cell number being $149.20 \pm 8.81,189.36 \pm 20.25$ and $237.21 \pm 7.13 \%$ at 24,48 and $72 \mathrm{~h}$, respectively (Fig. 3). The number of SCs treated with 0.1 , 1 and $10 \mathrm{ng} / \mathrm{ml}$ TSA increased to $169.99 \pm 0.68,178.64 \pm 12.00$ and $185.68 \pm 15.57 \%$ of the control at $24 \mathrm{~h}$, to $222.55 \pm 20.33$, $243.95 \pm 25.35$ and $262.24 \pm 22.28 \%$ of the control at $48 \mathrm{~h}$ and to $256.88 \pm 6.58,282.10 \pm 10.19$ and $297.03 \pm 14.72 \%$ of the control at $72 \mathrm{~h}$, respectively. Although at the early stage $(24 \mathrm{~h})$, there was no significant difference in the number of SCs between the various concentration groups $(\mathrm{F}=2.14, \mathrm{p}=0.172)$, TSA increased the number of SCs thereafter, i.e., at $48 \mathrm{~h}(\mathrm{~F}=5.27, \mathrm{p}=0.027)$ and $72 \mathrm{~h}(\mathrm{~F}=4.86, \mathrm{p}=0.033)$, compared to the control group at the same time points.

TSA inhibits the migration of SCs. To evaluate the effects of TSA on SC migration, Transwell chamber analysis was performed. As shown in Fig. 4, a smaller number of SCs was observed to migrate across the membranes in the groups treated with $0.1 \mathrm{ng} / \mathrm{ml}(\mathrm{p}<0.001, \mathrm{n}=6)$ and $1 \mathrm{ng} / \mathrm{ml}(\mathrm{p}<0.005, \mathrm{n}=4)$ TSA than in the control group $(n=6)$. This result indicated that TSA significantly inhibited the transmigration of SCs.

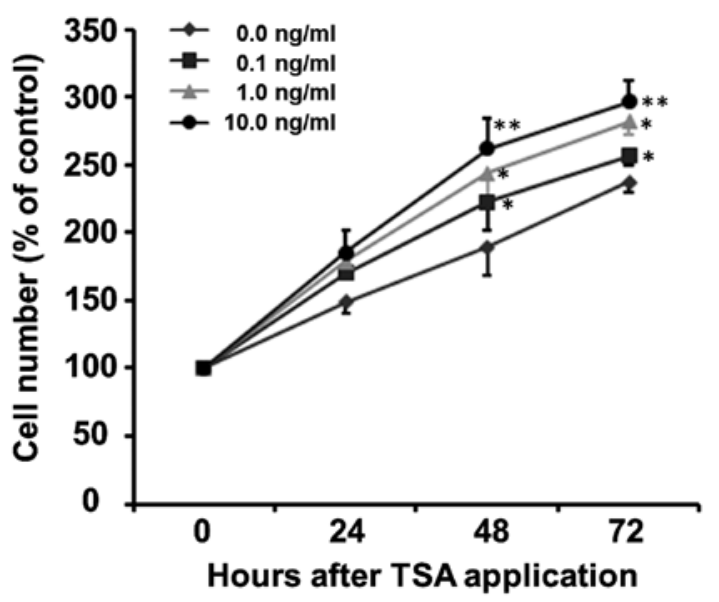

Figure 3. Trichostatin A (TSA) promotes the proliferation of Schwann cells (SCs). TSA increased the proliferation of SCs in a time-dependent manner. ${ }^{* *} \mathrm{p}<0.01, \mathrm{n}=3$, compared to original plate cells, ${ }^{*} \mathrm{p}<0.05, \mathrm{n}=3$, compared to the control at the same time point.

TSA increases the mRNA expression of neurotrophic factors in SCs. As shown in Fig. 5, RT-PCR indicated that the mRNA expression of brain-derived neurotrophic factor (BDNF) increased to $140 \pm 4.69 \%$ at $6 \mathrm{~h}(\mathrm{p}<0.005)$ and then decreased to $129.0 \pm 6.71(\mathrm{p}<0.05), 124.0 \pm 2.25(\mathrm{p}<0.001)$ and $98.0 \pm 5.24 \%$ ( $>0.05$ ) of the control at 12,24 and $48 \mathrm{~h}$, respectively, following TSA application. The mRNA expression of ciliary neurotrophic factor (CNTF) increased to $128.59 \pm 6.28(\mathrm{p}<0.05)$ and $133.36 \pm 9.82 \%(\mathrm{p}<0.05)$ at 6 and $12 \mathrm{~h}$, respectively, and then decreased to $87.44 \pm 2.25 \mathrm{p}>0.05$ ) and $45.9 \pm 6.16 \%$ $(p<0.001)$ of the control at 24 and $48 \mathrm{~h}$, respectively, following TSA application. The mRNA expression of fibroblast growth factor $(\mathrm{FGF})$ increased to $117.49 \pm 3.92(\mathrm{p}<0.05)$ and $120.59 \pm 4.14 \%(\mathrm{p}<0.01)$ at 6 and $12 \mathrm{~h}$, respectively, and then decreased to $118.97 \pm 4.67(\mathrm{p}<0.05)$ and $101.53 \pm 5.75 \%(\mathrm{p}>0.05)$ of the control at 24 and $48 \mathrm{~h}$, respectively following TSA application. The mRNA expression of glial growth factor (GGF) markedly increased to $278.32 \pm 47.59 \%(\mathrm{p}<0.05)$ at $6 \mathrm{~h}$, and then decreased to $195.34 \pm 13.31(\mathrm{p}<0.005), 130.93 \pm 26.33(\mathrm{p}>0.05)$ and $68.85 \pm 17.65 \%(\mathrm{p}>0.05)$ of the control at 12,24 and $48 \mathrm{~h}$, respectively, following TSA application. The mRNA expression of glial cell-derived neurotrophic factor (GDNF) increased to $145.14 \pm 15.23(\mathrm{p}<0.05)$ at $12 \mathrm{~h}$, and then decreased to a 

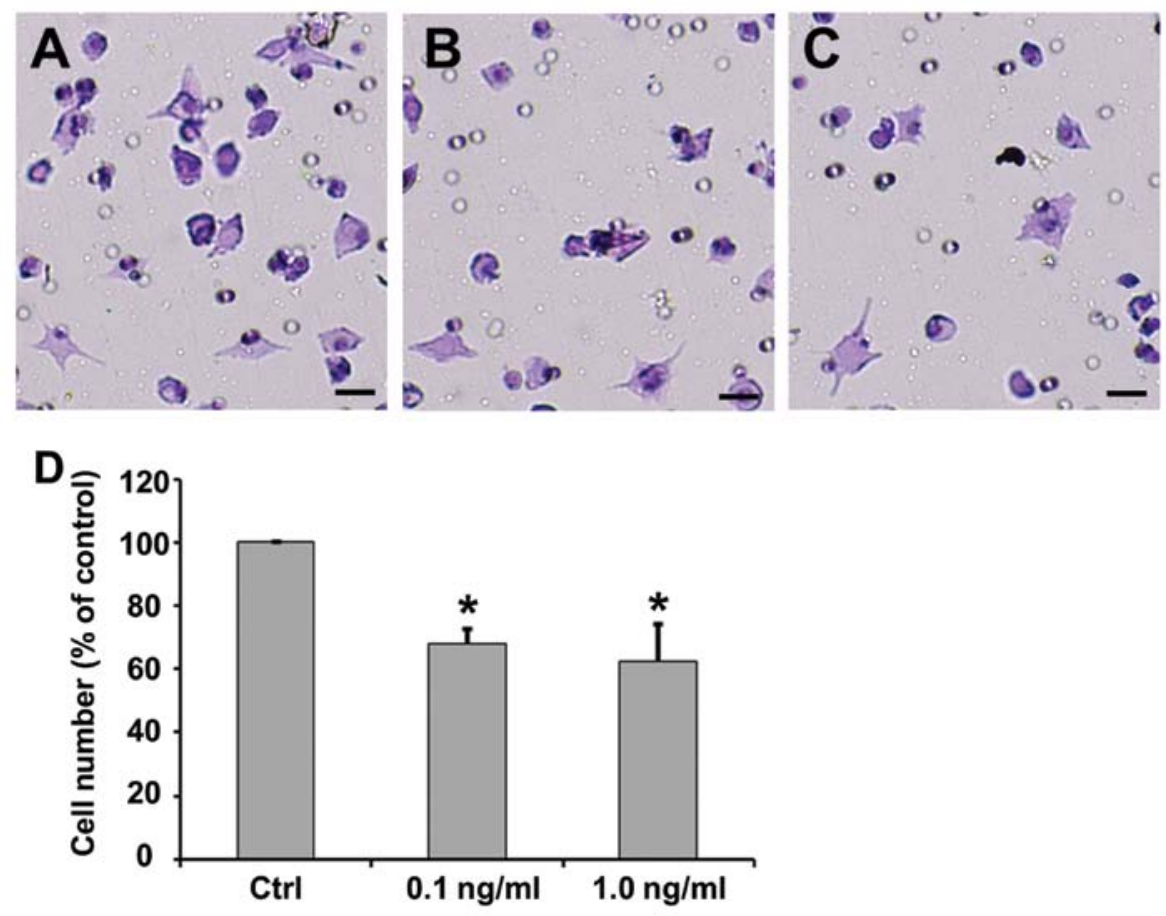

Figure 4. Trichostatin A (TSA) inhibits the migration of Schwann cells (SCs). SC motility was detected using Transwell chamber migration assays. A smaller number of SCs migrated down the membranes in the groups treated with $0.1 \mathrm{ng} / \mathrm{ml}$ and $1 \mathrm{ng} / \mathrm{ml} \mathrm{TSA}$ compared with the control (untreated) group. * $\mathrm{p}<0.05$, $\mathrm{n}=3$.

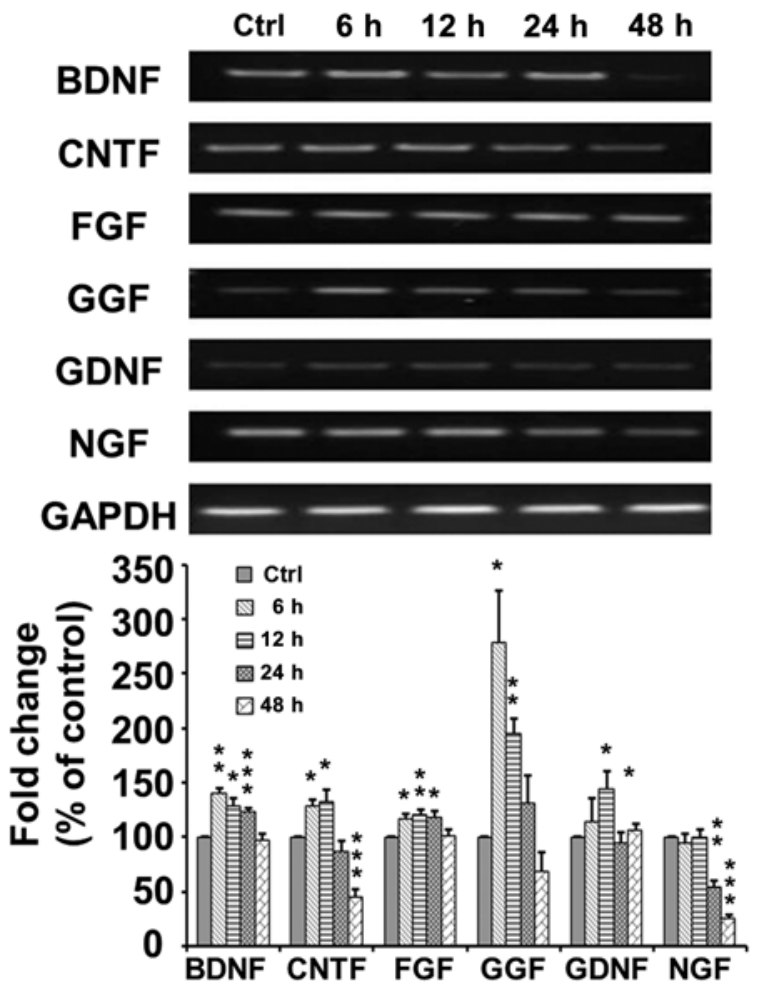

Figure 5. Effect of trichostatin A (TSA) on the mRNA expression of neurotrophic factors in Schwann cells (SCs). RT-PCR was used to determine the mRNA expression levels of brain-derived neurotrophic factor (BDNF), fibroblast growth factor (FGF), glial growth factor (GGF), glial cell-derived neurotrophic factor (GDNF), ciliary neurotrophic factor (CNTF) and nerve growth factor (NGF) at different time points following treatment with TSA.

normal level of $94.91 \pm 8.94 \%$ ( $>0.05)$ at $24 \mathrm{~h}$ following TSA application. However, the mRNA expression of nerve growth factor (NGF) remained at a normal level at 6 and $12 \mathrm{~h}$, but then decreased to $53.88 \pm 6.67 \%(\mathrm{p}=0.0023)$ at $24 \mathrm{~h}$ following TSA application.

TSA inhibits the mRNA expression of genes associated with myelination. The mRNA expression of genes associated with myelination, including MPZ and MBP, following $48 \mathrm{~h}$ of treatment with various concentrations of TSA was detected by qPCR. Our results revealed that TSA significantly inhibited the mRNA expression of MPZ to $4.83 \pm 1.59,3.00 \pm 2.00$ and $1.67 \pm 1.20 \%$ of the control at a concentration of $0.1(t=59.86, p<0.001), 1.0$ $(\mathrm{t}=48.5, \mathrm{p}<0.001)$ and $10 \mathrm{ng} / \mathrm{ml}(\mathrm{t}=81.82, \mathrm{p}<0.001)$ (Fig. 6). Similarly, TSA significantly inhibited the mRNA expression of MBP to $54 \pm 2.08,49.6 \pm 0.31$ and $63.03 \pm 2.98 \%$ of the control at a concentration of $0.1(\mathrm{t}=22.1, \mathrm{p}<0.001), 1.0(\mathrm{t}=164.97, \mathrm{p}<0.001)$ and $10 \mathrm{ng} / \mathrm{ml}(\mathrm{t}=12.39, \mathrm{p}<0.001)$ (Fig. 6).

\section{Discussion}

In the present study, we investigated the role of TSA, an HDAC inhibitor, on the survival, proliferation and migration of SCs, as well as on the the expression of neurotrophic factors and genes associated with myelination in SCs.

It has been reported that some HDAC inhibitors, such as TSA and VPA, have basal toxicity, and that prolonged treatment with TSA or VPA at high doses often induces neuronal death (23). Treatment with TSA has been shown to result in aggravated neurotoxic damage in dopaminergic neurons induced by 1-methyl-4-phenylpyridinium and rotenone (17), and to induce apoptotic and autophagic cell and ventral midbrain neuronal death induced by HDAC inhibitors through caspase-dependent or -independent cell death pathways $(24,25)$. However, in our previous study, we 


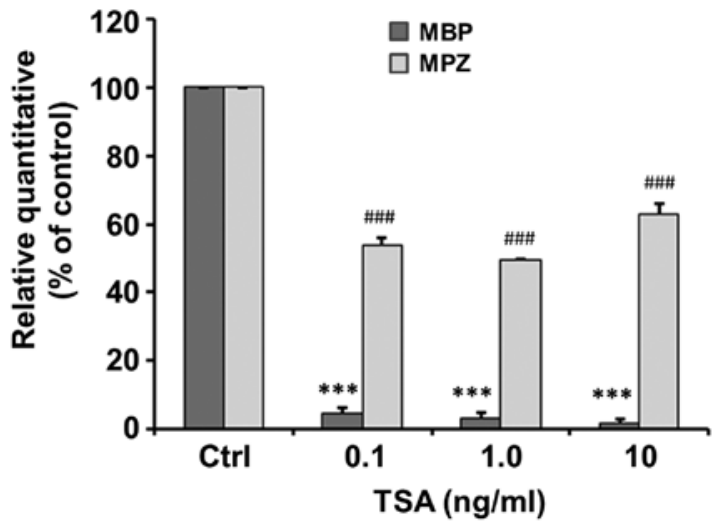

Figure 6. Trichostatin A (TSA) inhibits the mRNA expression of myelin-associated genes. The assay revealed that there was a significant decrease in the mRNA expression of genes associated with myelination in Schwann cells, such as myelin basic protein (MBP) and myelin protein zero (MPZ) after $48 \mathrm{~h}$ of treatment with TSA. ${ }^{\# \#} \mathrm{p}<0.01,{ }^{* * * *} \mathrm{p}<0.05, \mathrm{n}=3$.

demonstrated that the inhibition of HDAC activity had no direct effect on the survival of NPCs (18). Moreover, in the present study, our results demonstrated that $0.1-10 \mathrm{ng} / \mathrm{ml}$ of TSA had no significant effect on the survival of SCs, whereas a higher concentration $(100 \mathrm{ng} / \mathrm{ml})$ of TSA induced SC death, suggesting that HDAC inhibition may induce cell death in a cell type-specific and dose-dependent manner.

Previous studies have demonstrated that HDAC inhibitors promote the growth of cortical neuronal $(26,27)$ and endothelial cells (28). In the present study, we demonstrated that TSA increased SC proliferation, indicating that TSA is a mitogen for $\mathrm{SCs}$ in vitro. It has been reported that some HDAC inhibitors, e.g., VPA or TSA, increase the mRNA and protein levels of neurotrophins, such as BDNF, GDNF, neurotrophin-3 (NT-3) and vascular endothelial growth factor (VEGF) in cultured cells and brain regions $(18,29,30)$, and thus induce cell proliferation (31). In the present study, we demonstrated that TSA increased the expression of several neurotrophic factors, including BDNF, FGF, GGF, CTNF and GDNF; this increase in the expression of neurotrophic factors may be one of the mechanisms through which TSA induces the proliferation of SCs.

Cell movement or motility is a highly dynamic phenomenon that is essential to a variety of biological processes, such as the development of an organism (morphogenesis), wound healing, cancer metastasis and immune response (32). The migration of SCs is also an important aspect of remyelination following nerve injury. In the present study, we showed that TSA inhibited the migration of SCs. It has been previously demonstrated that neurotrophins, integrins, erythropoietin, GDNF and neuregulin $\beta-1$ (NRG1) regulate the motility and migration of SCs (33). Endogenous NT3 and BDNF are key regulators of SC migration, and promote or inhibit the migration of SCs, respectively (34). Similarly, endogenous and exogenous GDNF have different effects on the migration of SCs. It has been reported that GDNF promotes the motility of SCs in vitro (35), whereas SC migration along the sciatic nerve is not dependent on GDNF in vivo (36). Our results revealed that TSA exerts different effects on the expression levels of neurotrophins, indicating that TSA affects the migration of SCs through the regulation of neurotrophin expression levels.
An important function of SCs is to wrap around axons of motor and sensory neurons to form the myelin sheath. MPZ and MBP are two key indicators for the maturation and myelination of SCs (37). Our data demonstrated that TSA decreased the expression of MBP and MPZ in SCs, suggesting that TSA regulates the differentiation and myelination of SCs.

In conclusion, our data demonstrate that TSA, at certain concentrations, has no toxic effect on cells, induces proliferation, inhibits SC migration, increases the expression of neurotrophic factors and decreases the expression of MBP and MPZ. These findings provide new evidence of the direct effects of TSA on SCs. By identifying the changes occurring in SCs following treatment with TSA, we may broaden our understand of TSA-based treatment of SCI.

\section{Acknowledgements}

This study was supported by a grant from the National Natural Science Foundation of China (no. 30872667).

\section{References}

1. Sobani ZA, Quadr SA and Enam SA: Stem cells for spinal cord regeneration: current status. Surg Neurol Int 1: 93, 2010.

2. Garbossa D, Boido M, Fontanella M, et al: Recent therapeutic strategies for spinal cord injury treatment: possible role of stem cells. Neurosurg Rev 35: 293-311, 2012.

3. Hill CE, Hurtado A, Blits B, et al: Early necrosis and apoptosis of Schwann cells transplanted into the injured rat spinal cord. Eur J Neurosci 26: 1433-1445, 2007.

4. Lavdas AA, Papastefanaki F, Thomaidou D and Matsas R: Schwann cell transplantation for CNS repair. Curr Med Chem 15: $151-160,2008$.

5. Takami T, Oudega M, Bates ML, et al: Schwann cell but not olfactory ensheathing glia transplants improve hindlimb locomotor performance in the moderately contused adult rat thoracic spinal cord. J Neurosci 22: 6670-6681, 2002.

6. Ide C, Nakai Y, Nakano N, et al: Bone marrow stromal cell transplantation for treatment of sub-acute spinal cord injury in the rat. Brain Res 1332: 32-47, 2010.

7. Schaal SM, Kitay BM, Cho KS, et al: Schwann cell transplantation improves reticulospinal axon growth and forelimb strength after severe cervical spinal cord contusion. Cell Transplant 16: 207-228, 2007.

8. Kocsis JD and Waxman SG: Schwann cells and their precursors for repair of central nervous system myelin. Brain 130: 1978-1980, 2007.

9. Patel V, Joseph G, Patel A, et al: Suspension matrices for improved Schwann-cell survival after implantation into the injured rat spinal cord. J Neurotrauma 27: 789-801, 2010.

10. Redell JB, Moore AN, Ward NH III, Hergenroeder GW and Dash PK: Human traumatic brain injury alters plasma microRNA levels. J Neurotrauma 27: 2147-2156, 2010.

11. Yu IT, Park JY, Kim SH, et al: Valproic acid promotes neuronal differentiation by induction of proneural factors in association with $\mathrm{H} 4$ acetylation. Neuropharmacology 56: 473-480, 2009.

12. Feng HL, Leng Y, Ma CH, et al: Combined lithium and valproate treatment delays disease onset, reduces neurological deficits and prolongs survival in an amyotrophic lateral sclerosis mouse model. Neuroscience 155: 567-572, 2008.

13. Tsai LK, Tsai MS, Ting $\mathrm{CH}$, Wang SH and Li H: Restoring $\mathrm{Bcl}-\mathrm{x}(\mathrm{L})$ levels benefits a mouse model of spinal muscular atrophy. Neurobiol Dis 31: 361-367, 2008.

14. Ferrante RJ, Kubilus JK, Lee J, et al: Histone deacetylase inhibition by sodium butyrate chemotherapy ameliorates the neurodegenerative phenotype in Huntington,'s disease mice. J Neurosci 23: 9418-9427, 2003.

15. Langley B, D'Annibale MA, Suh K, et al: Pulse inhibition of histone deacetylases induces complete resistance to oxidative death in cortical neurons without toxicity and reveals a role for cytoplasmic p21 (waf1/cip1) in cell cycle-independent neuroprotection. J Neurosci 28: 163-176, 2008. 
16. Chuang DM, Leng Y, Marinova Z Kim HJ and Chiu CT: Multiple roles of HDAC inhibition in neurodegenerative conditions. Trends Neurosci 32: 591-601, 2009.

17. Wang Z, Zang C, Cui K, et al: Genome-wide mapping of HATs and HDACs reveals distinct functions in active and inactive genes. Cell 138: 1019-1031, 2009.

18. Liu $\mathrm{H}, \mathrm{Wu} \mathrm{H}$, Wang Y, et al: Inhibition of class II histone deacetylase blocks proliferation and promotes neuronal differentiation of the embryonic rat neural progenitor cells. Acta Neurobiol Exp (Wars) 72: 365-376, 2012.

19. Morrissey TK, Kleitman N and Bunge RP: Isolation and functional characterization of Schwann cells derived from adult peripheral nerve. J Neurosci 11: 2433-2442, 1991.

20. Xu XM, Guénard V, Kleitman N, Aebischer P and Bunge MB A combination of BDNF and NT-3 promotes supraspinal axona regeneration into Schwann cell grafts in adult rat thoracic spinal cord. Exp Neurol 134: 261-272, 1995.

21. Xu XM, Guénard V, V, Kleitman N and Bunge MB: Axonal regeneration into Schwann cell-seeded guidance channels grafted into transected adult rat spinal cord. J Comp Neurol 351 145-160, 1995.

22. Wang X, Fu S, Wang Y, et al: Interleukin-1beta mediates proliferation and differentiation of multipotent neural precursor cells through the activation of SAPK/JNK pathway. Mol Cell Neurosci 36: 343-354, 2007.

23. Jeong MR, Hashimoto R, Senatorov VV, et al: Valproic acid, a mood stabilizer and anticonvulsant, protects rat cerebral cortical neurons from spontaneous cell death: a role of histone deacetylase inhibition. FEBS Lett 542: 74-78, 2003.

24. Forgione N and Tropepe V: Histone deacetylase inhibition promotes Caspase-independent cell death of ventral midbrain neurons. Mol Cell Neurosci 48: 117-128, 2011.

25. Mi S, Lee X, Shao Z, et al: LINGO-1 is a component of the Nogo-66 receptor/p75 signaling complex. Nat Neurosci 7 221-228, 2004

26. Di Daniel E, Mudge AW and Maycox PR: Comparative analysis of the effects of four mood stabilizers in SH-SY5Y cells and in primary neurons. Bipolar Disord 7: 33-41, 2005.
27. Hao Y, Creson T, Zhang L, et al: Mood stabilizer valproate promotes ERK pathway-dependent cortical neuronal growth and neurogenesis. J Neurosci 24: 6590-6599, 2004.

28. Michaelis M, Suhan T, Michaelis UR, et al: Valproic acid induces extracellular signal-regulated kinase $1 / 2$ activation and inhibits apoptosis in endothelial cells. Cell Death Differ 13: 446-453, 2006.

29. Chen PS, Peng GS, Li G, et al: Valproate protects dopaminergic neurons in midbrain neuron/glia cultures by stimulating the release of neurotrophic factors from astrocytes. Mol Psychiatry 11: 1116-1125, 2006

30. Castro LM, Gallant M and Niles LP: Novel targets for valproic acid: up-regulation of melatonin receptors and neurotrophic factors in C6 glioma cells. J Neurochem 95: 1227-1236, 2005

31. Otsuka S, Adamson C, Sankar V, et al: Delayed intrathecal delivery of RhoA siRNA to the contused spinal cord inhibits allodynia, preserves white matter, and increases serotonergic fiber growth. J Neurotrauma 28: 1063-1076, 2011.

32. Ananthakrishnan R and Ehrlicher A: The forces behind cell movement. Int J Biol Sci 3: 303-317, 2007.

33. Heermann S and Schwab MH: Molecular control of Schwann cell migration along peripheral axons: keep moving! Cell Adh Migr 7: 18-22, 2013.

34. Ishida-Yamamoto A, Yamauchi T, Tanaka H, et al: Electron microscopic in situ DNA nick end-labeling in combination with immunoelectron microscopy. J Histochem Cytochem 47: 711-717, 1999

35. Cornejo M, Nambi D, Walheim C, et al: Effect of NRG1, GDNF, EGF and NGF in the migration of a Schwann cell precursor line. Neurochem Res 35: 1643-1651, 2010.

36. Heermann S, Spittau B, Zajzon K, Schwab MH and Krieglstein K: Schwann cells migrate along axons in the absence of GDNF signaling. BMC Neurosci 13: 92, 2012.

37. Jacob C, Christen CN, Pereira JA, et al: HDAC1 and HDAC2 control the transcriptional program of myelination and the survival of Schwann cells. Nat Neurosci 14: 429-436, 2011. 